\title{
Nik-Related Protein Kinase
}

National Cancer Institute

\section{Source}

National Cancer Institute. Nik-Related Protein Kinase. NCI Thesaurus. Code C88936.

Nik-related protein kinase (1582 aa, $178 \mathrm{kDa}$ ) is encoded by the human NRK gene. This

protein is involved in signal transduction. 